\section{Carnegie Fellowships in Neurophysiology}

THe Carnegie Corporation of New York has announced that it is making a grant of 75,000 dollars $(£ 26,785)$ to support fellowships in neurophysiology, psychology and biophysics to be held at the Autonomics Division of the National Physical Laboratory, Teddington. The Autonomics Division aims at devising self-governing machines to carry out mental tasks of increasing complexity and the study of related biological problems. Fellowships will be given to Americans with recent doctorates in psychology, physiology and other fields who are interested in neural organization and intelligence. The grant will cover a period of five years and the fellowships will be administered by the Carnegie Institution. The research projects will be agreed by the Carnegie Institution and the National Physical Laboratory.

\section{The Emmie Clough Scholarship in Horticulture}

THE Royal Horticultural Society is offering for award a scholarship provided out of a bequest from the late Mrs. Emmie Clough to enable a girl to take a course of training in horticulture which would otherwise be beyond the girl's means. The first scholarship, valued at $£ 352$ per annum, will commence in September 1962. It will be open to women betweon the ages of eighteen and thirty and will be tenable for two years at Studley College, Warwick. shire. Forms of application and further information can be obtained from the Secretary, Royal Horticultural Society, Vincent Square, London, S.W.1.

\section{Churchill College Fellowships}

Churchill College, Cambridge, is offering junior research fellowships in arts, mathematics, science and engineering to those who have been engaged in research in a university for not more than four years. The College is also offering a Gulbenkian Fellowship to the value of $£ 650$ per annum to a graduate of any University outside the United Kingdom. Further information can be obtained from the Senior Tutor, Churchill College, Cambridge.

\section{Announcements}

Prof. Arne Tiselius, For.Mem.R.S., professor of biochemistry in the University of Uppsala, Nobel Laureate in Chemistry (1948), has been awarded the Messel Medal of the Society of Chemical Industry for 1962.

Prof. Bengt Strömgren, of the Institute of Advanced Studies, Princeton, has been awarded the Gold Medal of the Royal Astronomical Society for his contributions to stellar and interstellar astrophysics. Prof. André Lallemand, of the Paris Observatory, has been awarded the Society's Eddington Medal for his work on photo-multipliers and particularly for his development of the electron camera.

The first award by the Paris Academy of Sciences of the Charles-Léopold Mayer Prize of 65,000 N.F. has been made to Dr. F. H. C. Crick, research worker for the Medical Research Council at the Council's Unit for Molecular Biology, Cambridge, for his work on nucleic acids, polyglycines and collagen.

Dr. C. O. MrLler, formerly an executive secretary in the Division of Chemistry and Chemical Technology, National Academy of Sciences-National
Research Council, has been appointed an executive secretary in the Research Fellowships Section of the Research Training Branch, Division of General Medical Sciences, National Institutes of Health, Bethesda, Maryland.

The U.S. Department of Health, Education and Welfare has issued a pamphlet entitled The Public Health Service in Radiological Health, which describes the function and aims of the Division and the opportunities of careers that it offers to professional personnel with an interest in radiological health. The pamphlet is available from the Division of Radiological Health, Public Health Service, Washington 25, D.C.

Memoirs and Proceedings of the Manchester Literary and Philosophical Society, Vol. 103, 1960-61 (Pp. 80+ liii. Manchester: Manchester Literary and Philosophical Society, 1961. 31s. 6d.) includes besides Sir Cyril Hinshelwood's address, "The Arts and Sciences", already noted in Nature (188, 448; 1960), A. S. C. Ross's Clayton Memorial Lecture, "The Pitcairnese Language", B. H. Flowers's Percival Lecture, "The Fundamental Structure of Matter", and papers by Lord Cohen of Birkenhead on "Peaks of Medical History" and Prof. Dorothy Emmet on "Social Philosophy in Britain and America". Some biographical notes on Thomas Henry, Thomas Barnes and Charles White by the late Dr. W. H. Brindley are also included.

No. 54 of the Current Bibliography on Analogue and Digital Computera and their Applications ('Titel von Veröffentlichunger über Analog und Ziffernrechner und ihre Anwendungen', 8, 1961/2 quarter. Pp. 93. Four issues yearly) contains 616 entries classified under four main and twenty secondary headings, with numerous subdivisions. In the entries the author, or authors, is given first, followed by title and bibliographical details, including price where relevant. The bibliography is obtainable from Franz Steiner Verlag, G.m.b.H. (subscription rate 96 D.M., for Institutes 76.80 D.M.).

THE annual conference of the Museums Association is to be held in Brussels during June 25-29. Further information can be obtained, from the Secretary, The Museums Association, 33 Fitzroy Street, Fitzroy Square, London, W.1.

A sympostum on "Nitrogen Heterocyclic Chemistry", arranged by Hatfield College of Technology with the support of the Chemical Society, is to be held in Hatfield during May 10-11. Further information can be obtained from Dr. R. F. Robbins, Hatfield College of Technology, Hatfield, Herts.

A symposrum on "The Organic Chemistry of Natural Products" is being organized by the Société Chimique de Belgique, which will be held in Brussels during June 12-15. Further information can be obtained from the Secretariat du Symposium International de Chimie Organique, c/o Federation des Industries Chimiques de Belgique, 32 rue Josoph II, Bruxelles 4.

Erratum. In the communication entitled "Chromium(III)-Oxyanion Systems", by G. M. Lukaszewski and J. P. Redfern (Nature, 190, 805; 1961), the heading of the column in Tables 1,2 and 3 at present reading "Activation energy $(E)$ kcal." should read: " $E / 2 \cdot 3 R$, where $E=$ activation energy keal. and $R=$ general gas constant". 